\begin{tabular}{c} 
International Journal of Basic and Applied Sciences, 5 (2) (2016) $105-109$ \\
International Journal of Basic and Applied Sciences \\
Website: $\begin{array}{c}\text { www.sciencepubco.com/index.php/IJBAS } \\
\text { ioi: } 10.14419 / \text { ijbas.v5i2.5299 } \\
\text { Research paper }\end{array}$ \\
\hline
\end{tabular}

\title{
Isolation and molecular characterization of Mycobacterium tuberculosis complex isolated from raw milk in some dairy farms in Egypt
}

\author{
Heba Hussien ${ }^{1}$, Eman Mahrous ${ }^{2}$ \\ ${ }^{I}$ Department of Food Hygiene \& Control, Faculty of Veterinary Medicine, Sadat City University \\ ${ }^{2}$ Department of Bacteriology, TB Unit, Animal Health Research Institute. Egypt \\ *Corresponding author E-mail: hebashelaby2013@yahoo.com
}

\begin{abstract}
This study was conducted to detect Mycobacterium tuberculosis complex in milk in three Egyptian Governorates; ElSharkia, El-Menoufia and El-Behera Governorates. 300 milk samples were collected from tuberculin positive cases, 18 (6.0\%) were shedding Mycobacterium tuberculosis complex in their milk which detected by real time PCR. On another hand, 170 milk samples were collected from tuberculin negative cases, 5 (2.9\%) were shedding Mycobacterium tuberculosis complex in their milk which detected by real time PCR. All milk samples were examined by three techniques including Microscopic examination, culture and real time PCR. Real time PCR is more rapid and accurate method than microscopic and culture method. The isolated colonies from culture were examined by Multiplex PCR to demonstrate the source of infection either human or animal source.
\end{abstract}

Keywords: Bovine Tuberculosis; Culture; Real Time PCR; Multiplex PCR; Egypt; Tuberculin Test.

\section{Introduction}

Bovine tuberculosis considered as a chronic infection in mammals caused by Mycobacterium tuberculosis complex, it remains an economic and public health problem for several countries. In developing countries, bovine tuberculosis is responsible for significant economical loss through decrease in milk production and decrease reproductive performance [1] .In Egypt, bovine tuberculosis was considered a serious public health problem as result of consumption of unpasteurized [raw milk] is a regular practice. It is one of the major zoonotic diseases worldwide due to its economic impact on international trade, contagious nature, and implications for human health [2].

$M$. bovis infection in cattle may involve in some cases udder lesion and the bacilli excreted in their milk due to septicemic and cutaneous infections. In both instances sufficient levels of Mycobacteria can be excreted from a single cow to make 100 gallons of previously non-contaminated milk infectious for infants. Raw milk and milk products are considered the main source of primary tuberculosis in children and infants [3]. Transmissions of tuberculosis to man are mainly by ingestion of raw milk or unpasteurized dairy products [4]. Moreover, by vertical or pseudo-vertical transmission due to consumption of milk from infected mothers or from close contact between mother and off spring [5]. This study was aimed to: Investigation of some dairy farms for detection of the prevalence of tubercle bacilli in milk, using of different diagnostic tools for detection of infected animals, genotyping of the isolates for determination of the sources of infection.

\section{Materials and methods}

\subsection{Sample collection}

470 milk samples were collected from some dairy farmers in El-Sharkia (200 samples), El-Menoufia (150 samples)) and El-Behera (120 samples) Governorates. Milk samples were collected from tuberculin positive cases as well as from tuberculin negative cases. All milk samples were examined by bacteriological procedures and real time PCR. The colonies were examined by multiplex PCR to identify the type of Mycobacterial colonies.

\subsection{Sample preparation}

$100 \mathrm{ml}$ of well mixed milk were centrifuged for $30 \mathrm{~min}$ at $3000 \mathrm{rpm}$.

\subsection{Ziehl-neelsen stains according to [6]}

The sediment of previously prepared samples was spread on clean slides. The slides were allowed to air dry, heat fixation then flooded using carbolfuchsin and left on a slide 
holder with heating under it (steaming not boiling). The slides washed thoroughly and decolorized using acid alcohol mixture followed by washing with water, then flooded with Loffler's methylene blue. Each slide was examined to detect the shape, arrangement and acid fastness.

\subsection{Culture of milk samples according to [7] and [8]}

After sample preparation, the resulting sediment is mixed with an equal volume of $1.8 \% \mathrm{HCL}$ and incubated at $37^{\circ} \mathrm{C}$ for $30 \mathrm{~min}$. The mixture is centrifuged for $30 \mathrm{~min}$. at 3000 rpm; the sediment is neutralized with $2 \%$ sterile $\mathrm{NaOH}$ sol., with Phenol red as an indicator, then, re-centrifuged for further examinations. Three to five drops of the decontaminated sediment were inoculated in two tubes containing Dorset egg media, other two containing Löwenstein-Jensen media with and without sodium pyruvate and Middle brook 7H10 agar media. Inoculated tubes were sealed and incubated at $37^{\circ} \mathrm{C}$ for at least 60 days with daily and then weekly observation (Except for Middle brook 7H10 agar media was incubated for maximum 24 days). The identification of isolated Mycobacteria was initially based on acid-fastness and microscopical morphology, observed in smears submitted to Ziehl-Neelsen stain, and in growth characteristics as time, temperature and colony features according to [9]. Then, the suspected colonies were submitted to the real time PCR.

\subsection{Real time PCR}

\section{a) Real Time PCR for milk sample:}

1. Extraction of DNA: (According to thermo scientific, Gene JET Genomic purification kit \#K0721, \#0722)

$400 \mu \mathrm{l}$ of lysis solution and $20 \mu \mathrm{l}$ of proteinase $\mathrm{K}$ were added to $200 \mu \mathrm{l}$ of milk sample, mixed thoroughly by vortexing or pipetting to obtain a uniform suspension. Then the sample was incubated at $56^{\circ} \mathrm{C}$ while vortexing occasionally or using a shaking water bath, rock platform or thermomixer until the cells are completely lysed (10 min.). About $200 \mu$ l of ethanol (96-100\%) was added and mixed by pipetting or vortexing. Transferred the prepared lysate to GeneJet Genomic DNA purofocation column inserted in a collection tube. Then centrifugation for $1 \mathrm{~min}$. at $6000 \mathrm{xg}$. The collection tube was discarded containing the flow- through solution. Placed the GeneJET Genomic purification column into a new $2 \mathrm{ml}$ collection tube (included). $500 \mu \mathrm{l}$ of wash buffer I (with ethanol) was added and centrifuged for $1 \mathrm{~min}$. at $8000 \mathrm{xg}$. The flow was discarded through and the purification column placed back into the collection tube. $500 \mu \mathrm{l}$ of wash buffer II (with ethanol) was added to the GeneJET Genomic purification column. Centrifugation for $3 \mathrm{~min}$. at maximum speed ( $\geq 1200 \mathrm{xg}$ ). The collection tube was discarded containing the flowthrough solution. The GeneJET Genomic purification column was placed into a sterile $1.5 \mathrm{ml}$ micro-cenrtifuge tube (not included). $200 \mu$ l of Elution buffer was added to the center of the GeneJET Genomic purification column membrane to elute genomic DNA. Incubation for $2 \mathrm{~min}$. at room temperature and centrifugation for $1 \mathrm{~min}$. at 8000 xg. The purification column was discarded .The purified DNA was used immediately in downstream application or store at $-20^{\circ} \mathrm{C}$.

2. Detection of M. tuberculosis complex.
Real time PCR was performed according to the kit obtained from biovision ${ }^{\circledR}$ Real-time PCR for milk samples and performed according to [10].The primers and TaqMan probe target a sequence conserved for all strains of each single species belonging to Mycobacterium tuberculosis complex. The reaction of $20 \mu \mathrm{l}$ final volume consisted of $10 \mu \mathrm{l}$ Hot Start-Mix qPCR 2X, $1 \mu$ l -qPCR-mix, $4 \mu$ l DNase/RNase free water and $5 \mu \mathrm{l}$ DNA sample. The reaction conditions consisted of one cycle of $95^{\circ} \mathrm{c}$ for $5 \mathrm{~min}$ followed by 45 cycles of $95^{\circ} \mathrm{c}$ for $30 \mathrm{sec}$ and $60^{\circ} \mathrm{c}$ for $60 \mathrm{sec}$ for hybridization, extension and data collection. The reaction was run in Applied Biosystem StepOne Real Time PCR System and FAM fluorogenic signal was collected and the cycle threshold of the reactions was detected by StepOne ${ }^{\mathrm{TM}}$ software version 2.2.2 [Life Technology].

\section{b) Multiplex PCR to differentiate between M. tuber- culosis and M. bovis strains: According to [11]:}

The DNA isolated from the suspected colonies by using DNA Purification Kit thermo scientific, GeneJET Genomic purification kit \#K0721, \#0722 were subjected to multiplex PCR by using two sets of primers:

The first set comprised of:

forward IS5 (CGGAGACGGTGCGTAAG) and reverse IS6 (GATGGACCGCCAGGGCTTGC) primers Amplifying a 984 bp genomic fragment of insertion sequence IS6110 specific for M. tuberculosis. The conditions were used as described by [12]. The second set contained forward JB21 (TCGTCCGCTGATGCAAGTGC) and reverse JB22(CGTCCGCTGACCTCAAGAAAG) primer amplifying a $500 \mathrm{bp}$ genomic fragment specific for $M$. bovis. The multiplex PCR reaction was performed in a final volume of $50 \mu \mathrm{l}$ containing $1 \times$ PCR buffer, $2.5 \mathrm{U}$ of Taq polymerase $0.2 \mathrm{mM}$ each deoxynucleoside triphosphate, 4.0 $\mathrm{mM}$ Magnesium chloride, and $150 \mathrm{~mol}$ of first primer set and $100 \mathrm{~mol}$ of second primer set. The target DNA denatured by incubation for $4 \mathrm{~min}$ at $94^{\circ} \mathrm{C}$ Before amplification for 30 cycles of $94^{\circ} \mathrm{C}$ for 30 seconds, annealing at $55^{\circ} \mathrm{C}$ for 30 seconds, and extension at $72^{\circ} \mathrm{C}$ for 45 seconds. The final extension was carried out at $72{ }^{\circ} \mathrm{C}$ for seven minutes. All reactions were carried out in an automated thermal cycler (Eppendorf, USA). After amplification, the PCR mixture was analyzed by gel electrophoresis in $1.5 \%$ agarose gel containing $0.5 \mu \mathrm{g} / \mathrm{ml}$ of ethidium bromide.

\section{Result}

Table 1: Prevalence of Mycobacterium Tuberculosis Complex in examined milk samples from some dairy farmers.

\begin{tabular}{lccccccc}
\hline Govern- & $\begin{array}{c}\text { No of } \\
\text { sam- } \\
\text { ment. }\end{array}$ & $\begin{array}{c}\text { Microscope } \\
\text { ples }\end{array}$ & $\begin{array}{c}\text { Culture } \\
\text { sam- } \\
\text { ples }\end{array}$ & $\begin{array}{c}\text { Real time } \\
\text { PCR } \\
\text { +ve } \\
\text { sam- } \\
\text { ples }\end{array}$ & $\begin{array}{c}\text { \% } \\
\text { +ve } \\
\text { sam- } \\
\text { ples }\end{array}$ & $\%$ \\
\hline Sharkia & 200 & 3 & 1. & 5 & $\begin{array}{c}2 . \\
5\end{array}$ & 8 & 4 \\
Menoufia & 150 & 0 & 0 & 1 & 0. & 9 & 6 \\
Behera & 120 & 2 & 1. & 3 & $\begin{array}{c}2 . \\
7\end{array}$ & \\
\hline
\end{tabular}


Table 2: Shedding Status within Tuberculin Positive Cases in Some Dairy Farms' Milk Samples Using Real Time PCR.

\begin{tabular}{ccc}
\hline \multirow{2}{*}{ Total tested milk samples } & \multicolumn{2}{c}{ Positive samples } \\
& No. & $\%$ \\
\hline 300 & 18 & 6.0 \\
\hline
\end{tabular}

Table 3: Shedding Status within Tuberculin Negative Cases in Some Dairy Farms' Milk Samples Using Real Time PCR.
Table 4: Identification of the Species of Mycobacterium Isolated From Milk Samples by Multiplex PCR.

\begin{tabular}{ccc}
\hline $\begin{array}{c}\text { Total examined colo- } \\
\text { nies }\end{array}$ & $\begin{array}{c}\text { Species of Mycobacte- } \\
\text { rium }\end{array}$ & $\begin{array}{c}\text { Number of the } \\
\text { species }\end{array}$ \\
\hline \multirow{2}{*}{9} & M. bovis & 5 \\
& M. tuberculosis & 3 \\
Mott & 1 \\
\hline
\end{tabular}

\begin{tabular}{ccc}
\hline Total tested milk samples & \multicolumn{2}{c}{ Positive samples } \\
& + ve & $\%$ \\
\hline 170 & 5 & 2.9 \\
\hline
\end{tabular}

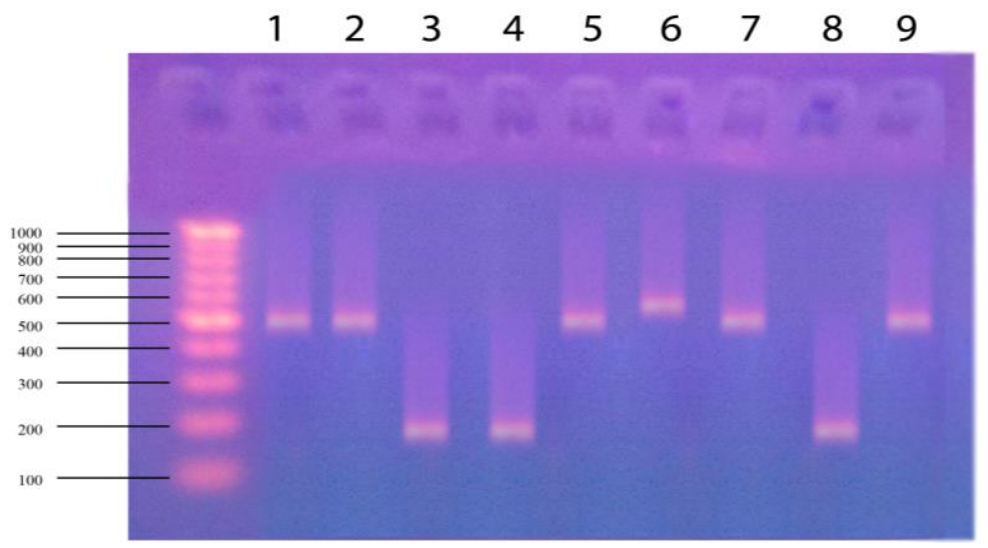

Fig. 1: Agarose Gel Electrophoresis of Serial 10-Fold Dilution of M. Tuberculosis Complex DNA Amplified by Multiplex-PCR. Lanes M: DNA Molecular Mass Marker (100-Bp Ladder). Lanes 1, 2, 5, 7, 9 Shows Product corresponding to 500 Bp Was Detected in M. Bovis, whereas Lanes 3, 4, 8 Shows Product of 185 Bp was Always Detected in M. Tuberculosis. Lane 6 Shows Product Higher Than 500 Bp Which Is Corresponding To MOTT.

\section{Discussion}

Tuberculosis is a multi-factorial disease in which complex environmental interactions with host related factors contribute to the overall disease phenotype. Understanding the individual balance between degree of exposure and inherited genetic susceptibility to infection will have strong implications on tuberculosis control and prevention [13]. Among the infectious diseases, TB holds one of the highest mortality rates worldwide. Eighteen people are affected with TB every minute globally and three of them die per minute [14]. Concerning the results of Microscopical examination of Mycobacterium tuberculosis complex , the results revealed that in El- Sharkia Governorates, out of 200 examined milk samples $3(1.5 \%)$ were positive samples .In contrast, all of examined milk samples were negative from 150 examined samples in El-Menoufia Governorate. While in El- Behera Governorate, out of 120 examined milk samples 2 (1.7\%) were positive samples by microscopical examination. Nearly similar results were recorded by [15] who detected 3 $(4.4 \%)$ were positive samples out of 68 examined milk samples by microscopical examination in Iraq. On the other hand, in Egypt [16] found relatively higher results of 3 $(6 \%)$ out of 50 milk samples examined microscopically. The low detection percentage of the organism in milk samples was explained by [6] and [17] who stated that demonstration of TB microscopically needs at least 100000 bacilli which lower the sensitivity of microscopical examination. Comparing the results of culturing of milk samples with those of microscopical examination revealed relatively higher detection percentages. Out of 200, 150 and 120 examined milk samples from El-Sharkia, El-Menoufia and El-
Behera Governorate. 5 (2.5\%), 1 (0.7\%) and 3 (2.5\%) samples were positive for the culture technique, respectively. The higher recovery rate of the culture than the microscope was discussed by [6] who proved that, the tissue samples must contain from 10 to 100 tubercle bacilli for having a positive results by using culture. lower incidence by culturing method may attributed to presence of other associated microorganisms which would hinder the growth of mycobacterium that cannot withstand prolonged incubation period, the inability of Mycobacterium isolates to adapt to in vitro culture conditions, especially in condition where the number of bacilli are limited, which could result in false negative results by culture [15]. Also, the variability in the methods of identification and the composition of the media used for primary isolation. In Tanzania, [18] found that out of 805 milk samples that were collected, 31 (3.9\%) were positive by culture. Moreover, in Egypt higher results were obtained by [19] (5.6\%). In Brazil, [20] found 78 (10\%) positive samples out of 780 milk samples examined by culture which is higher than our obtained results. Furthermore, [21] in Pakistan conducted a study at Lahore and isolated $M$ bovis from milk samples of four cows out of $16(25 \%)$ with confirmed bovine tuberculosis. Also, higher results were detected in Canadian cattle in Ethiopia by [22] out of examined 1171 animals there were $548(46.8 \%)$, that is due to the intensive system of housing at which the imported cattle were kept and leads to lowering the immune system of the cattle. Moreover, in Iraq, [15] conducted a study on 68 raw milk sample; the positive rates for culture were 7 (10.2\%). Also, similar results in Egypt were obtained by [23] who mentioned that, in some private farms in Egypt, Mycobacterial culture of milk samples revealed $(4.35 \%)$ of the collected 23 bovine milk samples were positive for $M$. bovis 
isolation. Moreover, similar results were obtained by [10] In Tunisia who proved that, out of 102 SCITT positive cows, 5 were detected as shedders of $M$. bovis in their milk. Also, similar results were detected by [24] who mentioned that, in Brazil mycobacteria isolated from $24(8 \%)$ out of examined 300 milk samples.

All samples were tested and confirmed using real time PCR. The obtained results revealed that, in El- Sharkia Governorate, out of 200 examined milk samples; there were 8 (4\%) positive samples. In El-Menoufia Governorate, $9(6 \%)$ out of 150 examined milk samples were positive. While in El- Behera Governorate, out of 120 examined milk samples, there were $6(5 \%)$ positive samples. The higher detection results of real time PCR was discussed by [15] who proved that only three bacilli in milk samples sufficient to be detected by real time PCR. Also, he recorded 7 (10.3\%) positive samples which are higher than that obtained by culture, as the PCR give high sensitivity and specificity for the Mycobacterium.

Moreover, real time PCR is more accurate and faster than conventional method for TB diagnosis [25]. As early diagnosis of TB disease is crucial in initiating treatment and interrupting the strain transmission. Rapid diagnosis will prevent the development of drug resistant M. tuberculosis [26]. Similar results were obtained by [27] who detected 11 (5.5\%) positive samples. On contrast [28] failed to detect any positive cases among 30 examined milk samples.

Despite all the fore mentioned results, the use of the PCR method in milk samples does not guarantee that it would perform equally effectively in the analysis of all infected samples. One could expect that in the latter, the interaction between the bacilli and the milk matrix could be more complex, and even that bacilli in milk might have already been killed by mammary macrophages [29] and the DNA partially degraded.

Result in table [2] revealed that out of $18[6.0 \%$ ] from 300 examined milk samples from tuberculin positive cases from examined dairy farms' were positive by using real time PCR. In contrast, 5 (2.9\%) were positive by using real time PCR from 170 examined milk samples from tuberculin negative cases from examined dairy farms'. This result explained that the negative effects of tuberculosis cannot be accurately evaluated because infected animals excrete bacteria for a non-determined period [20]. There are many limitations to the SID tuberculin test have been reported for the diagnosis of bovine tuberculosis [30]. This result agree with [31] and [32] who stated that tuberculin reactivity is not a reliable indicator of active disease and/or tuberculous infection in cattle. [31] Stated that half of isolates of M. bovis and M. tuberculosis were obtained from animals that were tuberculin negative. Tuberculous animals have not only a sanitary or economical relevance, but infected cows can also disseminate pathogens through their milk, which, according to World Health Organization, is responsible for transmission of another 15 bacterial diseases [33] and [34].

To differentiate between different types of Mycobacteria, multiplex PCR was carried out and the results were tabulated in table [4], revealed that, among the nine isolated strains from the examined milk samples, five strains were belonged to $M$. bovis, three were belonged to M. tuberculosis and the reminder strains was MOTT. Isolation of atypical Mycobacteria from milk is of public health significance because as most of them proved to be potentially pathogenic to man especially immunocompromised individuals [35].
Higher percentages than our findings were detected in Egypt by [36] who detected 16 isolates of $M$. bovis and 8 isolates of $M$. tuberculosis. Nevertheless, in addition to the results of the present study, M. tuberculosis has also been isolated from cows' milk in Ethiopia by [37].

Lower results were obtained in Brazil by [2] who detected 1 $(0.78 \%)$ M. bovis strains from 128 examined milk samples. Moreover, in Ecuador [38] isolated 4 M. bovis only from 29 samples and owed the reason to the stage of the disease at the time of sampling and the difficulty in isolation of the Mycobacterium. [39] Proved that, the other possible source of M. tuberculosis in milk is the contamination by the cough spray from infected farmers during milking. Whatever the case, the presence of $M$. tuberculosis in milk is of grave public concern, as it is primarily raw milk that is consumed in Ethiopia. In Nigeria, [40] indicated that the presence of M. tuberculosis in milk indicating post milking contamination from human and unhygienic practices associated with milking process. Furthermore, [41] detected M. bovis from $(12 \%)$ of milk samples obtained from tuberculin positive cow cases. It is well established that cattle infected with $M$. bovis can excrete the bacillus in their milk. However, it is not likely that cattle infected with M. tuberculosis would excrete the bacillus in their milk since they rarely develop TB due to $M$. tuberculosis. Lower results were detected in Brazil by [24] who detected only one $M$. bovis among examined 300 milk samples. Moreover, [3] mentioned that $M$. bovis infection in cattle may involve in some cases udder lesion and the bacilli excreted in milk or sheded in their milk due to septicemic and cutaneous infections. In both instances sufficient levels of Mycobacteria can be excreted from a single cow to make 100 gallons of previously non-contaminated milk.

\section{References}

[1] Boland, F., Kelly, G. E., Good, M. and More, S. J. (2010): Bovine tuberculosis and milk production in infected dairy herds in Ireland. Prev. Vet. Med. 93:153-161.

[2] Leite F, Anno I, Leite S, Roxo E, Morlock G, Cooksey R (2013): Isolation and identification of Mycobacteria from livestock specimens and milk obtained in Brazil. Mem Inst Oswaldo Cruz vol 98 319-323. http://dx.doi.org/10.1590/S0074-02762003000300005.

[3] Connell TG, Curtis N, Ranganathan S C, Buttery J P (2006): Performance of a whole blood interferon gamma assay for detecting latent infection with Mycobacterium tuberculosis in children. Thorax 61 [7] 616-620. http://dx.doi.org/10.1136/thx.2005.048033.

[4] Domo GA and Ishaku Japhet (2015): The presence of Mycobacterium species in raw milk obtained from lactating cows in lewa and duda of vimtim wards, mubi north. Nov. Appl Sci., 4 [1]: 7-12.

[5] Medeiros L, Marassi C, Figueiredo E, Walter Lilenbaum (2010): potential application of new diagnostic methods for controlling bovine tuberculosis in Brazil. Brazilian $\mathrm{J}$ Microb 41: 531-541. http://dx.doi.org/10.1590/S1517-83822010005000002.

[6] Cruickshank R, Duguid P, Marmion P, Swain a (1975): Medical Microbiology. Vol. 11 part I: Churchill living stone. Edinburgh, London and New York.

[7] Quinn, P. J.; Carter, M. E.; Markey, B. and Carter, G. R. (1994): Mycobacterium species. Clinical veterinary microbiology. London: Wolfe, P. 156-169.

[8] Corner, L. A.; Trajstman, A. C. and Lund, K. L. (1995): determination of the optimum concentration of decontamination for the primary isolation of Mycobcterium bovis. New Zealand veterinary Journal, 43 http://dx.doi.org/10.1080/00480169.1995.35871.

[9] Ernst LB (1990). Mycobacteria species: The Agents of Animal Tuberculosis. In Ernst L. Biberstein and Yuan Chung Zee (Ed). Review of Vet. Microbiol. Blakwell Scientific Pub., INC. Boston, Oxford, London, Edinburgh, Melbourne. Ch. 28, Pp. 202-212.

[10] Ben kahla; Boschiroli, ML; Souissi, F.; Cherif, N.; Benzarti, M.; Boukadida, J., and Hammami, S. (2011): isolation and molecular 
characterization of Mycobacterium bovis from raw milk in Tunisia. African Health Science, 11, (S1) S2-S5.

[11] Mumtaz N.; Iqbal Z., Mahmood N., and A.R Shakoori (2008): Reliability of PCR for Detection of Bovine Tuberculosis in Pakistan. Pakistan J. Zool., vol. 40 [5], pp. 347-351.

[12] Barouni A S, Augusto C J, Lopes M T, Zanini M S, Salas C (2004): A pncA polymorphism to differentiate between Mycobacterium bovis and Mycobacterium tuberculosis. Mol Cell Probes 18: 167170. http://dx.doi.org/10.1016/j.mcp.2003.11.006

[13] Siddiqui M, Fakih H, Burney W, Iftikhar R, Khan N (2011): Environmental and host related factors predisposing to tuberculosis in Karachi: A cross- Sectional Study. J PAK MED STUD 1 [1].

[14] WHO (2013): Tuberculosis and gender, E-Focus: Newsletter of the WHO Global TB Programme.

[15] Al-Saqur, I. M.; A. N. Al-Thwani and I. M. Al-Attar (2009): Detection of Mycobacteria spp in cow's milk using conventional methods and PCR. Iraqi Journal of Veterinary Sciences, 23 (II) 2009 (259 262) Proceedings of the 5th Scientific Conference, College of Veterinary Medicine, University of Mosul.

[16] Wahba N, Nasr S, Saad N, Nasr E A, Elsherif W (2013): Detection of bovine tuberculosis in milk and serum of tuberculin reactors dairy farm animals in Assuit City, Egypt. Basic Res J Anim Sci. Vol 1 pp 1-6.

[17] Duguid, J. P.; Marmion, B. P. and Swain, R. H. A. (1978): Mackie\& MacCartney, Medical Microbiology. Microbial infections, $13^{\text {th }}$ Ed. Vol 1, a guide for the laboratory diagnosis and control of infection.

[18] Kazwala, R.R., Daborn, C.J., Kusiluka, L.J.M., Jiwa, S.F.H., Sharp, J.M. \& Kambarage, D.M. [1998]: 'Isolation of Mycobacterium species from raw milk of pastoral cattle of the Southern Highlands of Tanzania', Tropical Animal Health and Production 30, 233-239. http://dx.doi.org/10.1023/A:1005075112393.

[19] Gad EWA, El-Abeedy A, Mettias KN, Manal a (2000): The present state and public health importance of tuberculosis of bovine udder. J. Egypt. Vet. Med. Ass., 60 (6. 189- 194).

[20] Renata Bonini PARDO; Hélio LANGONI; Lia Jeanne Pereira MENDONÇA; Kung Dahr CHI (2001): Isolation of Mycobacterium spp. in milk from cows suspected or positive to tuberculosis. Braz. J. Vet. Res. Anim. Sci. 38 [6].

[21] Hamid, J.; Puran, D. and Asif, S. (2003): Bovine TB in Lahor- Public Health Veterinary service, Metropolitan corporation Lahor, Pakistan.

[22] Ameni G, Aseffa A, Engers H, Young D, Gordon S, Hewinson G, Vordermeier M (2007): High prevalence and increased severity of pathology of bovine tuberculosis in Holsteins compared to zebu breeds under field cattle husbandry in central Ethiopia. Clin Vaccine Immunol. 14 [10]: 1356-61. Epub 2007 Aug 29.PubMed PMID: 17761523; PubMed Central PMCID: PMC2168113. http://dx.doi.org/10.1128/cvi.00205-07.

[23] Hassanain N, Hassanain M, Soliman Y A, Ghazy A, Ghazyi Y. A (2009): Bovine tuberculosis in a dairy cattle farm as a threat to public health. Afr J Microbiol Res Vol 3 [8] pp 446-450.

[24] Franco MM, Paes AC, Ribeiro MG, de Figueiredo Pantoja JC, Santos AC, Miyata M, Leite CQ, Motta RG,and Listoni FJ (2013): Occurrence of mycobacteria in bovine milk samples from both individual and collective bulk tanks at farms and informal markets in the southeast region of Sao Paulo, Brazil. BMC Vet Res. 2013 Apr 24; 9: 85. http://dx.doi.org/10.1186/1746-6148-9-85.

[25] Grange JM, Collins JD, O'Reilly L, Costello E, MD. (1990): Identification and characteristics of Mycobacterium bovis isolated from cattle, badgers and deer in the Republic of Ireland. IrVet J. 43:3335.

[26] Al-jebory, I.S. (2006): Screening and DNA fingerprinting based on IS6110 of Mycobacterium tuberculosis complex isolated from pulmonary patients in Iraq. ph.D. Thesis, Genetic Engineering and biotechnology Institute for Graduate Studies, Baghdad University.

[27] Silaigwana B, Green E, Ndip RN (2012): Molecular detection and drug resistance of Mycobacterium tuberculosis complex from cattle at a dairy farm in the Nkonkobe region of South Africa: A pilot Study. Int J Environ Res public health 9 2045-2056. http://dx.doi.org/10.3390/ijerph9062045.

[28] Ereqat S, Nasereddin A, Levine H, Azmi K, Al- Jawabreh A, Greenblatt Ch, Abdeen Z, Bar-Gal G (2013): First time detection of Mycobacterium bovis in livestock tissues and milk in the west Bank, Palestinian Territories.PLOSNTDs 7 [9].

[29] Zumarraga, M. J., Martin, C., Samper, S., Alito, A., Latini, O., Bigi, F., Roxo, E., Cicuta, M.E., Errico, F., Ramos, M.C., Cataldi, A., Soolingen, D \& Romano, A.A. (1999). Usefulness of Spoligotyping in Molecular Epidemiology of Mycobacterium bovis- Related In- fectious in South America. Journal of Clinical Microbiology. P.296-303

[30] Koo HC, Park YH, Ahn J, Waters WR, Palmer MV, Hamilton MJ, Barrington G, Mosaad AA, Park KT, Jung WK, Hwang IY, Cho SN Shin SJ and Davis WC (2005). Use of rMPB7D protein and ESAT6 peptide as antigens for comparison of the Enzyme-linked immunosorbent, immunochromatographic and latex based agglutination assays for serodiagnosis of bovine tuberculosis. Journal of Clinical Microbiology 43: $4498 \quad-\quad 4506$. http://dx.doi.org/10.1128/JCM.43.9.4498-4506.2005.

[31] Srivastava, K. D.S. Chauhan, P. Gupta, H.B. Singh, V.D. Sharma, V.S. Yadav, Sreekumaran*, S.S. Thakral J.S. Dharamdheeran, P. Nigam*, H.K. Prasad \& V.M. Katoch (2008): Isolation of Mycobacterium bovis \& M. tuberculosis from cattle of some farms in north India - Possible relevance in human health. Indian J Med Res 128: 26-31.

[32] Neill, S.D., Hanna J, Mackie DP and Bryson TG. (1992): Isolation of Mycobacterium bovis from the respiratory tracts of skin test negative cattle. Vet Rec .131: 45-7. http://dx.doi.org/10.1136/vr.131.3.45.

[33] Bobenrieth, R.; Beltrán, F. El medico (1984): veterinário en la protección de alimentos y el control de zoonosis. Boletín de la Oficina Sanitaria Panamericana, 97, [2]: 298-313.

[34] Brandão, S. C. C. (1994): Leite legislação, responsabilidade e saúde pública. Revista Balde Branco, 360. 68-71.

[35] Grang, J. M. (1990): The mycobacteria in: Topley \& Wilson "Principles of Bacteriology, Virology and Immunity" $9^{\text {th }}$ Ed. Parker, M. and Duerden, B. L. Vol. 111p. 94- 121. (Eds) Edward Arnold, a division of Holder and Stonghton, London, Melbourne, Auckland.

[36] Guindi, S. M.; Ahmed, O. L.; Awad, W. M. and El- Sabban, M. S. (1982): incidence of bovine and human tubercle bacilli in milk and milk products. Agriculture Research Review 58, 75-84.

[37] Kiro, K. (1998): Epidemiology and zoonotic importance of bovine tuberculosis in selected sites of Eastern Shoa. MSc thesis. Faculties of Veterinary Medicine of Addis Ababa University and Frè̀e Universtät, Berlin.

[38] Proaño-Pérez, F.; Rigouts, L.; Brandt, J.; Dorny, P.; Ron, J.; Chavez, M. A.; Rodríguez, R.; Fissette, K.; Van Aerde, A.; Portaels, F.; Benítez-Ortiz, W.: (2006): Preliminary observations on Mycobacterium spp. in dairy cattle in Ecuador. American Journal of Tropical Medicine and Hygiene. V. 75 Issue: 2, 318-323.

[39] Regassa A., Ameni G. \& Medhin G. (2007): Risk factors for the transmission of Mycobacteria between farmers and their cattle in central Ethiopia. Vet. J. (in press)

[40] OFukwu, R. A.; Oboegbulem, S. I., and Akwuobu, C. A. (2008): Zoonotic Mycobacterium species in fresh cow milk and fresh skimmed, unpasteurized market milk (nono) in Makurdi, Nigeria: implications for public health. Journal of animal and plant sciences, vol. 1, issue 1:21-25.

[41] Figueiredo ES, Junior AC, Furlanetto LV, Silva FG, Duarte RS, Silva JT, Lilenbaum W, Pascoalin VM (2012). Molecular techniques for identification of species of the Mycobacterium tuberculosis complex: The use of multiplex PCR and an adapted HPLC method for identification of Mycobacterium bovis and diagnosis of bovine tuberculosis. In: understanding tuberculosis - Global experiences and innovative approaches to the Diagnosis. 411-432. Dr. Pere-Joan Cardona (Ed.). 